\title{
LITERATURA E CINEMA: ROMPENDO O SILÊNCIO SOBRE A ANDROGINIA E O HOMOSSEXUALISMO
}

Risolete Maria Hellmann (UFSC)

Resumo: Este estudo comparativo entre a obra cinematográfica Servindo em Silêncio, de Jeef Bleckner (1995) e o romance $A$ Sentinela de Lya Luft (1994) pretende discutir o modo como se dá o rompimento do silêncio sobre a representação de sujeitos marcados pela androginia e homossexualidade. Margarethe, no filme, e Henrique, no romance, são figuras andróginas. Ela assume ser lésbica e rompe o silêncio e ele dissimula a identidade sexual. Escritora e diretor possibilitam as discussões acadêmicas no campo da criação artística literária e cinematográfica.

Palavras chave: androginia; homossexualismo; silêncio.

Abstract: This comparative study between the cinematographic work Serving in Silence direct by Jeef Bleckner (1995) and the novel A Sentinela written by Lya Luft (1994) discusses how it gives the breakdown of silence on the representation of subject marked by androgyny and homosexuality. Margaret, in the film, and Henrique, in the novel, are androgynous figures. She takes being a lesbian and breaks the silence and he conceals his sexual identity. Writer and director enable academic discussions in the field of literary and cinematic artistic creation.

Keywords: androgyny; homosexuality; silence.

Cinema e literatura constituem criações artísticas autônomas, no entanto é possível identificar entre elas semelhanças como artes narrativas. Levando em consideração distinções e semelhanças possíveis este é um trabalho comparativo entre o filme Servindo em Silêncio, um drama dirigido por Jeef Bleckner (1995) nos Estados Unidos, e o romance A Sentinela da escritora brasileira Lya Luft (1994). 
Comparando o filme e o romance, três enfoques aparecem já numa primeira leitura: a androginia, o homossexualismo e ainda o silêncio, ou a quebra do silêncio, em relação as duas questões anteriores.

O filme conta a estória de Margarethe Cammermeyer, interpretado por Gleen Close. Ela tem uma carreira promissora dentro do Exército. Está há 25 anos nas Forças Armadas, recebeu estrela de bronze no Vietnã, prêmio de enfermeira do ano, nove promoções, é especialista em neuro-oncologia e vai se doutorar em enfermagem. É coronel e pretende chegar a general. Tanto fisicamente quanto pelas atitudes é uma figura andrógina. Ela tem um relacionamento homossexual com Diane (Judy Davis) que é pintora e professora universitária. Ao responder algumas questões ao Departamento de Investigação do Exército, declara-se lésbica, o que para o Departamento de Defesa constitui "comportamento imoral". Sob pressão de seus superiores para que retire o que disse, bem como de seu pai e de sua amada, cada qual com seus motivos, Margarethe inicia sua luta pela igualdade de direitos. Ao ser dispensada, processa o Exército por discriminá-la enquanto homossexual.

A Sentinela de Lya Luft é uma narrativa em primeira pessoa onde a protagonista (Nora) conta sua estória e, 
consequentemente, a dos familiares. O que mais nos interessa neste trabalho são as abordagens sobre a androginia e a homossexualidade que a mãe comenta ao falar da sua relação com seu filho único, Henrique. Ela vê nele o reflexo da irmã morta e ao mesmo tempo traços do pai dela. Em suas reflexões comenta a androginia do próprio filho. E quando este inicia sua vida adulta, em meio a silêncios significativos, aparece uma discussão fragmentada, repleta de vazios, sobre o possível homossexualismo de Henrique.

Guaciara Lopes Louro afirma que:

Em nossa sociedade, a norma que se estabelece, historicamente, remete ao homem branco, heterossexual, de classe média urbana e cristão e essa passa a ser a referência que não precisa mais ser nomeada. Serão os "outros" sujeitos sociais que se tornarão "marcados", que se definirão e serão denominados a partir dessa referência. Desta forma, [...] gays e lésbicas são descritos como desviantes da norma heterossexual.

Ao classificar os sujeitos, toda sociedade estabelece divisões e atribui rótulos que pretendem fixar as identidades. Ela define, separa e, de formas sutis ou violentas, também distingue e discrimina. $(2000$, p.9)

As duas obras permitem uma reflexão sobre as questões relacionadas com a afirmação e o reconhecimento das 
diferenças de gêneros, as quais têm sido uma constante ao longo dos séculos, desafiando, quer a hierarquia, quer os estereótipos resultantes da polarização masculino/feminino. As formas como a autora e o diretor abordam a temática homoafetiva possibilita discutir o modo como se dá a representação desses sujeitos considerados fora do padrão da heteronormatividade, que os distingue e descrimina de forma violenta no filme e de forma mais sutil no romance.

Assim como na vida, tanto na arte cinematográfica quanto na arte literária performances andróginas e/ou homossexuais enfrentam a intolerância secular infligida às minorias, as quais sofrem discriminação nos contextos sociais, profissionais e familiares e são incitados à marginalização. Contudo, se por séculos o silêncio se impôs sobre essas questões, como a pós-modernidade possibilita o rompimento desse silêncio?

\section{MASCULINO E FEMININO: DUAS METADES EM UM...}

Androginia não é assunto novo, pois desde a Grécia Antiga, o feminino e o masculino fundiam-se de tal forma que se tornavam praticamente indestrinçáveis. Etimologicamente, o vocábulo andrógino provém do grego androgynos, resultante de "andro (homem) e gyne (mulher): que participa dos dois sexos" (MONNEYRON, 1994, p.17). 
De formas diversas, a androginia sempre esteve representada nas artes. No poema épico A llíada de Homero (séc. IX a.C.) a androginia ressalta no mito de Tirésias; também em Platão temos a referência ao Mito do Andrógino (428-347 a.C.), em $O$ Banquete, assim como esse último também faz referência ao amor homossexual masculino, representando o valor androcêntrico de sua sociedade. Naquele contexto, a homossexualidade não era vista como anomalia, como foi considerado na Europa do século XIX, quando foi explicada por termos da psicologia.

Ainda para Monneyron (1994), a maioria dos autores dos finais do século XIX, ingleses ou franceses, ao representar o andrógino davam-lhe a forma do jovem efeminado e não a junção entre seres do mesmo sexo. Essas representações aparecem em obras de autores como Swinburne, Wilde ou Péladan.

Porém, é no século $X X$ que ressaltam as preocupações de escritores(as) e cineastas ao abordarem o assunto, quando fatores sociais e políticos começam a esfumaçar as diferenças entre homens e mulheres. Olhando a questão da perspectiva da crítica feminista, por exemplo, algumas características que as mulheres assumiram com a luta pelo direito ao voto, ao divórcio, à independência financeira, ou mesmo contra a estereotipia dos papéis sociais 
foram consideradas másculas. E não são poucas as obras literárias ou cinematográficas que passaram a apresentar personagens andróginas.

Em Orlando, Virginia Woolf trabalha o mito do andrógino, não deixando claro o sexo do protagonista. Na narrativa fílmica, criada a partir da adaptação obra literária, Orlando, a Mulher Imortal, o protagonista Orlando é representado por Tilda Swinton. O lorde inglês, adorado pela rainha, encontrase enfermo depois de uma desilusão amorosa e acorda com a alma de uma mulher.

Na literatura brasileira, a título de exemplo, Riobaldo e Diadorin, personagens de Grande Sertão: veredas, escrito por Guimarães Rosa, representam tanto a aparente androginia quanto o amor homoafetivo. De modo semelhante, no cinema japonês, outro exemplo de androginia e homossexualidade é o filme de Nagima Oshima (1999), Tabu (Gohatto). Na narrativa fílmica, um jovem de 18 anos, Sazoburo, é selecionado para uma tropa de elite de samurais no Japão medieval, que têm por missão defender o Shogun, mas sua beleza e androginia faz com que vários dos guerreiros se apaixonem por ele.

Como a lista de narrativas literárias e filmes que abordam as duas questões é relativamente grande, isso nos permite entender que as artes são veículos privilegiados para 
representar a beleza andrógina, pois essa não é perecível, é eterna, não passa pela destruição para ser (re)criada, diferentemente da natureza que atravessa o ciclo da vida, morte e renascimento. Contudo, voltemos às obras aqui selecionadas para reflexão, ou seja, $A$ Sentinela de Lya Luft e Rompendo o Silêncio de Jeef Bleckner.

No filme, Margarethe tem uma expressão facial andrógina, todos os seus traços físicos estão hibridizados na excelente interpretação de Gleen Close, uma bela atriz. Vista de perfil apresenta traços masculinos, mas num outro ângulo ressaltam traços femininos com a ajuda de uma maquiagem leve, o uso de brincos e de seu próprio cuidado com a aparência. Seu jeito de andar, ou até de sentar em determinadas situações é todo masculino, tanto na vida pública quanto privada. No entanto a afetividade, o sentimento de maternidade aflora na relação com os filhos. É meiga e carinhosa com Diane e a nora se identifica com o modelo de mulher que ela é em casa, no âmbito privado.

Em diversas situações ela aparece em tarefas culturalmente ditas femininas, como cozinhando, servindo a mesa ou cuidando do pai já idoso. No seu vestuário prevalecem roupas masculinas, no entanto, em ocasiões especiais, como o casamento do filho ou durante o 
julgamento do processo, ela usa vestidos, denotando a intencionalidade do diretor em ressaltar a dupla aparência. Também na intimidade do lar está de vestido, algumas vezes acompanhado de avental.

Dentro da própria situação profissional a androginia ressalta, pois a enfermagem culturalmente é uma profissão feminina e exige sensibilidade da profissional no trato com doentes. Ao mesmo tempo, Margarethe assume atitudes ditas másculas no campo profissional, pois ela enfrenta tudo com coragem, determinação e autoridade. A sua carreira repleta de medalhas, promoções e a sua ambição de ser a enfermeira chefe de toda a Guarda Nacional, como General do Exército é próprio deste contexto masculino travestido de universal.

Em diversas cenas ela chora por desespero, mas a sua luta pela igualdade de condições não está relacionada ao fato de ser mulher, pois sua competência profissional não está em jogo. Aliás, é em função dessa eficiência que ela é pressionada a silenciar sua homossexualidade, o que vamos comentar mais à frente. Margarethe não esconde, nem silencia sua emotividade, pois, enquanto mãe, ela representa característica culturalmente tidas como femininas. Chora ao falar da rejeição e da frieza do pai (pelo fato de ser mulher) e do quanto gostaria de ser reconhecida por ele. Chora ao 
falar da sua primeira experiência de maternidade e fica feliz quando sabe que vai ser avó.

Uma das cenas marcantes criadas por Bleckner (1995), em que ele usa a técnica conhecida como montagem dialética ou intelectual, na qual duas imagens da protagonista se alternam repetidamente, permitem ao espectador formar um novo significado implícito. Em uma das imagens, a protagonista está no tribunal, vestida de oficial do Exército, assumindo uma postura masculina; em outra ela está em casa em atividades domésticas, vestida em roupas coloridas, caracteristicamente femininas. Enquanto os planos visuais se alternam, a voz em off lê o veredicto, no qual ela perde o reconhecimento federal. Técnica cinematográfica que é capaz de comprovar a afirmação de Rosiska Oliveira (1993, p.128): “No andrógino as duas culturas (masculino e feminino) coexistem e convivem, disfarçadas em uma só."

Enquanto no filme a androginia pode ser interpretada por meio da imagem visual, pela técnica cinematográfica e pelas atitudes da protagonista, no romance ela aparece no próprio discurso da narradora-protagonista, Nora, quando fala do filho em suas divagações.

A narradora em primeira pessoa busca explicações para a "sutil androginia" do filho: 
Os genes que tramavam seus finos fios fazendo brotar semelhanças entre as gerações - aqui o nariz do avô, ali o gesto da mãe, ali ainda, o modo do pai virar a cabeça - me tranquilizavam relativamente, quando eu olhava Henrique e via minha irmã morta. À noite, muitas vezes, porém, o chão da certeza científica, dessa natural evidência, começava a rachar, aqui e ali abriam-se gretas ameaçadoras, o que seria isso? Por que esse jeito de Lilith, essa sutil androginia, o cabelo igual, o mesmo nariz, algumas manias? O hábito de sentar no chão, pernas cruzadas, botando no meio o bicho de pelúcia...? (LUFT, 1994, p.123)

É cultural a dificuldade que Nora tem de aceitar a androginia de Henrique, pois ela foi ensinada a esperar de seu filho determinada fisionomia e atitudes masculinas. Mas como não consegue deixar de perceber, mesmo que não comente o assunto, procura explicações científicas para os fatos. Masculino e feminino são os "finos fios" que se entrelaçam em todos nós, mas o que reprime mais um desses fios, normalmente, são os preconceitos, os tabus repassados em diversas culturas. Daí as "gretas ameaçadoras" quando o chão começa a rachar.

Da mesma forma que no filme, masculino e feminino são ressaltados tanto fisicamente quanto nas atitudes de 
Henrique, ou melhor, na leitura que a mãe faz dele, porque quase tudo passa pela voz da narradora. A aparência física feminina se entrelaça ao masculino resultando uma figura ambígua: "O rosto de Henrique é Lilith; os olhos, Mateus: a vida trança seus fios arcaicos, o que é belo mas assusta." (LUFT, 1994, p.16). A beleza secular do Ser andrógino é lembrada por Lya Luft, através da voz ficcional de Nora. Por outro lado, essa figura andrógina assusta porque, de acordo com Elisabeth Badinter:

a norma imposta foi o contraste, a oposição [...] O ideal é parir um ser humano unissexuado: um homem 'viril', uma mulher 'feminina'. Mas os adjetivos revelam o que se quer esconder: toda uma série de intermediários possíveis entre os dois tipos ideais. (1992, p.236)

Seu conflito maior não é o fato de Henrique apresentar traços de Lilith ou de Mateus, mas o fato de ser Lilith e de ser Mateus, ou seja, ser feminino e masculino concomitantemente.

Mesmo se, em alguns momentos, ela parece aceitar a androginia (quando busca explicações científicas, por exemplo) vive os conflitos, a angústia gerada pela permanente observação da aparência física e vontade de controlar as atitudes dele. Esses conflitos trazem na raiz os conceitos normativos da heterossexualidade em que a mãe está inserida, os quais estabelecem modos de ser, de 
parecer e de agir para homens e mulheres, conforme seu sexo, como construções culturais.

Em outros momentos, ela descobre nele características masculinas: "muitas vezes, quando ele fala comigo, é como se Mateus me espiasse neste rosto tão diferente e continuasse me vigiando." (LUFT, 1994, p.16) E é por essa alternância de características masculinas e femininas que ela o classifica como "diferente", mas poderíamos perguntar: Diferente de quem? Ou de que modelo? Nesse sentido, o discurso da narradora, marcado por preconceitos e tabus, parece perpassado por uma visão androcêntrica da realidade. Nas palavras de Pierre Bourdieu "[...] a visão androcêntrica impõe-se como neutra e não precisa de se enunciar em discursos visando legitimá-la. A ordem social funciona como uma imensa máquina simbólica tendendo a ratificar a dominação masculina em que assenta [...]" (1999, p.9). Os modelos do homem "viril" e da mulher "feminina" já estão legitimados nessa perspectiva e tudo que difere disso causa esse estranhamento que a mãe narradora sente.

Como toda a leitura da androginia é realizada pela própria narradora-protagonista, fica difícil discernir as fantasmatizações do imaginário de Nora e a concretização da androginia de Henrique. Voltamos aqui à questão das 
informações, na obra literária, serem repassadas apenas pela linguagem linear e fragmentada. Percebemos aqui a falta das outras formas de repassar informações utilizadas no cinema. No entanto, Lya Luft, investida da sua narradora, evidencia a questão sem os mesmos escrúpulos e preconceitos que esta.

Comparando o filme ao romance, apesar das diferenças das duas formas de arte, é possível concordar com Elisabeth Badinter quando diz que

as mulheres vivem sua bissexualidade melhor do que os homens. Asseguradas de sua feminilidade, elas utilizam e manifestam sua virilidade sem reticências. Alternando com facilidade papéis masculinos e femininos, segundo os períodos da vida ou os momentos do dia, elas não têm o sentimento de que sua bissexualidade seja uma ameaça para sua identidade feminina: pelo contrário, ressentem a alteridade como a condição de uma existência mais rica e menos determinada antecipadamente. (1992, p.245)

Margarethe é uma figura ambivalente, que vive, ou exprime a contradição, o conflito dos dois sexos num só, alterna com facilidade os papéis masculinos e femininos dependendo das circunstâncias que o momento lhe exige. No entanto, Henrique é ambíguo, pois não assume a situação, esquiva-se para não enfrentar a mãe e nem o mundo, para 
não se comprometer, prefere fugir, fazer longas viagens. Os papéis masculinos e femininos confundem-se em Henrique, não importando a circunstância, ou o momento do dia, mas em Margarethe eles estão bem definidos e distribuídos.

Cabe ressaltar que androginia e homossexualismo não são causa e consequência, no nosso ponto de vista, o que nos faz trabalhar as duas temáticas juntas é a presença do silêncio significante em cada uma. Contudo, antes do silêncio, falemos da representação do homossexualismo nas duas obras.

\section{HOMOSSEXUALISMO: AINDA UMA HORRENDA QUESTÃO?}

Em Servindo em Silêncio, o homossexualismo é a questão central, em torno da qual a narrativa se desenvolve. Ao declarar-se lésbica, numa entrevista oficial ao Departamento de Investigação do Exército, que define homossexualidade como "conduta imoral", Margarethe transgride os limites aceitos, culturalmente, como normais. Ela estava transgredindo o que o Exército prescreve como bom "comportamento moral".

Esse sistema prescritivo normalmente é dado pela cultura desse grupo ou pelos indivíduos que o formam. Margarethe tinha consciência disso e uma das razões para ir até as últimas consequências era o fato de acreditar que poderia 
derrubar o sistema opressor dos papéis sexuais, que tornava compulsório a heterossexualidade já naturalizada.

Enquanto era pressionada a se retratar, para poder continuar exercendo a profissão, chegou a afirmar que em todo o mundo as mudanças só ocorrem quando alguém se expõe, para as pessoas saberem que existem diferenças e que isso é normal. Além disso, ela tinha escolhido estar ali.

Assim, Margarethe deixara de ser o modelo ideal de moral ao declarar-se lésbica, por isso foi reprovada e dispensada da sua função.

A não aceitação dessa transgressão no espaço público já não acontece no âmbito da vida privada, ou seja, na família. Um dos filhos escolhe morar com ela depois da revelação; o outro filho e a esposa vão depor a favor dela no julgamento e afirmam que se tornaram mais próximos; outro enfrenta as agressões dos colegas de colégio quando o caso é publicado nos meios de comunicação. O pai dela, mesmo com toda sua intransigência, autoritarismo e visão androcêntrica, vem morar com ela. A princípio, ele finge que elas são somente "amigas" e aceita Diane naturalmente, apesar disso, também está sempre do lado da filha em situações conflituosas.

Esse filme vem confirmar que na pós-modernidade não se quer apagar a tradição da heterossexualidade, mas quer- 
se o reconhecimento da "diferença" das identidades. Como coloca Louro (2000, p.4), o debate sobre as identidades e as práticas sexuais e de gênero vem se intensificando desde a década de 1970, provocado principalmente pelos movimentos: feminista, de gays e de lésbicas.

No filme, durante a entrevista, o investigador pergunta por que Margarethe se considera lésbica e ela responde que ser lésbica faz parte da identidade de uma pessoa. Ele insiste e pergunta quantos relacionamentos sexuais ela já teve com mulheres e ela responde: "Não disse que já tive. Me envolvo emocionalmente com mulheres... Não tem nada a ver com sexo. São sentimentos." (BLECKNER, 1995). Era a afirmação da identidade homossexual, ou seja, da diferença e, concomitantemente, a luta pela igualdade de direitos em relação aos heterossexuais.

De fato, não houve evidência no filme que ressaltasse o homoerotismo de Margarethe e Diane, um nítido teor sexual, mas sim a existência de um amor homossexual, beirando a atração física, mas seguindo caminhos bem mais emocionais.

Ao contrário do filme, no romance $A$ Sentinela o homossexualismo é masculino e aparece mais como hipótese do que assumido. Tudo passa pela preocupação, pelas suspeitas da mãe de Henrique (o suposto homossexual). 
O assunto vem à tona durante uma discussão entre os dois onde ele diz: "- Não entendi direito suas alusões, suas indiretas, mas você...você por acaso quer saber se eu tenho um namorado?" (LUFT, 1994, p.112, grifo da autora). As suspeitas da mãe começaram quando algum tempo antes ele havia resolvido usar cabelo comprido e ela, mesmo achando bonito, não concordava. Em outro momento, ele mostra que está usando brinco. "Um minúsculo brinco; discreto, mas um brinco. Foi uma briga séria. - Onde se viu, filho meu de brinco?" (LUFT, 1994, p.108) dizia ela.

A não aceitação de Nora, logicamente, está relacionada à questão dos preconceitos e tabus repassados através da cultura opressora da sociedade em que viviam. Ela havia sido educada, ou melhor, domesticada para a heterossexualidade. Qualquer manifestação contrária a esses preceitos devia ser reprimida. Considerando que, conforme Louro "a sexualidade é 'aprendida', ou melhor, é construída, ao longo de toda a vida, de muitos modos, por todos os sujeitos" (2000, p.5), os cabelos longos e o brinco minúsculo e discreto do filho são marcas culturais da moda que se instaurou na segunda metade do século XX e alteram práticas de identidade sexual de forma explícita, mas que continuam a ser "renovadamente, reguladas, condenadas ou negadas." (LOURO, 2000, p.4) 
Henrique, não desfaz as dúvidas levantadas pela mãe, não responde suas insinuações claramente, por isso, nós leitores que praticamente só recebemos informações através dessa narradora em primeira pessoa, pois a autora cala a voz dos outros personagens, também não resolvemos nossas dúvidas sobre o homossexualismo dele. O que é possível perceber é que ele aguça a curiosidade da mãe:

- Mãe, você insiste nessa história de uma namorada, de que Pedro está casado há anos, mulher grávida. Mãe, estou avisando, me deixe em paz. [...] Nem vou me casar, acho que não, de modo que sou em tudo diferente do que você sonhava. (LUFT, 1994, p.111)

Mas em nenhum momento da narrativa algo na postura dele demonstrou sua homossexualidade, o que faz a discussão sobre o tema ficar mais interessante. É a autora, usando a máscara da narradora protagonista, que parece querer estabelecer o diálogo com os leitores sobre a homossexualidade. Na voz da personagem está marcado o preconceito, o tabu até para falar abertamente sobre o assunto com o filho, representando dessa forma a realidade contextual da época narrativa que ainda via o homossexual com restrição e evitava falar sobre isso, ou o coloca na marginalidade. 


\section{ROMPER OU FICAR EM SILÊNCIO?}

A noção de silêncio que utilizamos aqui não é sinônimo de vazio, mas vamos tratar do silêncio significante, no sentido orlandiano da expressão.

No filme aqui analisado, há o rompimento do silêncio em várias circunstâncias. $O$ diretor não cala a androginia de Margarethe, na riqueza de informações transmitidas através da imagem cinematográfica. Rompe-se também o silêncio com relação à existência da homossexualidade feminina. Este dá a impressão de ser mais categórico (o que não significa que seja), pois além da imagem, o texto aborda o tema como central na narrativa. Ao rompê-los, logicamente, comprovase a identidade do cinema na pós-modernidade que assume as vozes da alteridade.

Mas o que mais chama a atenção é o posicionamento do contexto público e privado da protagonista que, em busca da própria identidade e na luta pela igualdade de direitos, rompe corajosamente o silêncio a que Margarethe tinha se legado.

Dos membros da sua família, os filhos e o ex-marido sempre souberam, mas nunca falaram no assunto e este silêncio é o que Eni Orlandi (1993) chama de "silenciamento político constitutivo", ou seja, sempre tiveram um diálogo "aberto" sobre todos os outros assuntos, mas não falavam 
neste para que ele não viesse à tona. O pai foi informado formalmente, através de uma carta direta e objetiva: "Antes de se mudar para cá precisa saber que acabo de descobrir que sou homossexual... Não posso e não esconderei quem sou de você." (BLECKNER, 1995). A partir daí começa a pressionála: "Não sei por que fica contando para todo mundo. E seu senso de privacidade?" (BLECKNER, 1995). O pai representa a autoridade, a visão androcêntrica com todos os resquícios do patriarcalismo, daí estar sendo um dos censores, que quer proibi-la de sustentar seu discurso publicamente para poder calar o sentido contido nele.

Diane tenta, inutilmente, persuadi-la a desistir do processo contra o Exército, porque ela mesma é uma figura ambígua, que tanto na vida pública, quanto privada silencia sua própria identidade homossexual. Esse silêncio pode significar medo, falta de personalidade ou uma falsa auto-preservação.

Mas a pressão maior é de outra instância de poder, o Exército. Margarethe é uma profissional eficiente, respeitada até então e, do ponto de vista de seus superiores, indispensável no seu local de trabalho. No entanto, eles são regidos pela lei opressora que nega a alteridade, que é capaz de aniquilar a identidade do sujeito. De acordo com Eni Orlandi (1993, p.110), para que a censura funcione, o 
sujeito precisa assumir a responsabilidade sobre o que ele diz, não necessariamente o que faz. A grande problemática não é o fato de ser homossexual, mas o fato de declarar-se publicamente assim.

Apesar de todas as tentativas, no plano formal e informal dos seus superiores, ela está irredutível, pois se ela silenciar estará concordando com o regulamento e ela quer mudá-lo. Chega a receber uma proposta de um superior:

O regulamento tem uma brecha: 'A menos que se comprove que o membro não é homossexual...' E se comprovarmos isso? Podia ser uma crise de meia idade, uma síndrome pós-trauma ou uma crise nervosa. Você pode retirar o que disse. [...] Se cometer assassinato terá mais chance de ficar. (BLECKNER, 1995)

Mas ela não aceita a imposição do silêncio e como uma porta-bandeira desse gênero leva ao universo autoritário, opressor do Exército, um discurso que o mundo ainda não se acostumou a ouvir.

Em A Sentinela também há silêncio tanto em relação à androginia quanto ao homossexualismo, mas diferentemente do filme os personagens ficam em silêncio. E é nessa existência dos silêncios que os sentidos afloram.

Elisabeth Badinter afirma que "cabe à educação calar as ambiguidades e ensinar a recalcar a outra parte de si." (1992, 
p.236) Norma, culturalmente responsável pela educação de Henrique, queria um homem "viril", daí querer calar o Outro em Henrique e o tentou através do silenciamento político:

Nem com Olga se mencionavam certas coisas, como por exemplo a semelhança crescente de Henrique com Lilith. Nunca, nem uma vez, comentamos isso, que era tão evidente; e não comentarmos me agoniava ainda mais. (LUFT, 1994, p.102)

Não falar sobre o assunto significava uma tentativa de eliminar a possibilidade da androginia. Mas por que não aceitála? Porque não conseguia transgredir as normas impostas por uma cultura opressora. No entanto, isso a agoniava, as dúvidas permanentemente afloravam na sua mente.

O próprio Henrique refugiava-se num mundo só seu, silenciando sobre si mesmo:

Henrique não era mais...um menininho doce, a quem eu conduzia. Começou a se rebelar...resistia. Não gritava...fechavase em si, mudo, e era uma miniatura de Lilith, escapando para um mundo impenetrável para mim. (LUFT, 1994, p.104)

Resistia ao poder dominador da mãe, que até então o "conduzia", que calava sua androginia e a forma que encontrou para assumir seu lado feminino foi escapar para um mundo silencioso e impenetrável pelo opressor. 
Norma, uma verdadeira "sentinela", na sua acentuada vigilância, funcionava como uma censura para Henrique que, politicamente, silenciava, como forma de resistência. Ela tinha consciência da atitude de Henrique, por isso algumas vezes cedia às vontades dele, "para que ele não se fechasse naquele mutismo, naquele mundo de olho parado, ausente." (LUFT, 1994, p.105). O silêncio sobre o homossexualismo é bem mais significativo, é carregado de preconceitos por parte de Norma.

O silenciamento político de Norma é o que Eni Orlandi (1993) denomina constitutivo, pois ela não permite que o assunto venha à tona para que não ultrapasse os limites do imaginário dela: "Recuei, virei-me, fugi para meu quarto e só saí de lá de madrugada [...] Henrique saíra de casa ficou várias semanas em casa de amigos, eu tinha notícias dele por Olga, a quem ele telefonava." (LUFT, 1994, p.112). Já o silenciamento político de Henrique é o que ela denomina de local, pois é provocado pelo efeito da censura do poder dominante e funciona como forma de resistência a esse poder.

\section{CONSIDERAÇÕES FINAIS}

Lya Luft e Jeff Bleckner rompem o silêncio abordando as temáticas da androginia e homossexualidade e se valem da arte para atuar de forma engajada no seu momento 
histórico-político-social no sentido de promover a reflexão e o debate sobre as novas identidades sociais. Essa postura vem mostrar que, na pós-modernidade, a partir das conquistas obtidas, tanto por movimentos sociais, quanto por pesquisas desenvolvidas nas academias, a literatura e o cinema não contam mais as mesmas histórias que omitem as diferenças de gêneros, ou mesmo representam o andrógino como um jovem efeminado. Margarethe é uma mulher de meia idade, uma profissional renomada, mas andrógina e, assumidamente, lésbica. Henrique, também andrógino, entra na vida adulta durante a narrativa sem perder essas características que fundem o masculino e o feminino, no entanto, a autora deixa em aberto sua opção sexual.

E apesar das diferenças entre as duas formas de arte, as semelhanças temáticas abordadas rompem o silêncio das vozes da alteridade. Rompimento esse, necessário para que mudanças ocorram também no contexto histórico-social, promovendo a igualdade de direitos e o reconhecimento das diferentes identidades. 


\section{REFERÊNCIAS}

BADINTER, Elisabeth (1992). Um é o outro. 2.ed. São Paulo: Círculo do Livro.

BOURDIEU, Pierre (1999). A Dominação Masculina. Oeiras: Celta Editora. LOURO, Guarciara Lopes et al (2000). Educação sexual: Pedagogias da sexualidade. Belo Horizonte: Autêntica.

LUFT, Lya (1994). A sentinela. São Paulo: Siciliano.

MONNEYRON, Frédéric (1994). L'Androgyne Romantique du Mythe au Mythe Littéraire, Grenoble: Ellug.

OLIVEIRA, Rosiska Darcy de (1993). Elogio da Diferença. O feminino emergente. São Paulo: Brasiliense.

ORLANDI, Eni Puccinelli (1993). .As formas do silêncio: no movimento dos sentidos. Campinas: Editora da UNICAMP.

PLATÃO (2001). O Banquete. São Paulo: Edições 70.

ROSA, João Guimarães (2001). Grande sertão: veredas. 19.ed. Rio de Janeiro: Nova Fronteira.

BLECKNER, Jeff (dir.) (1995). Servindo em Silêncio EUA.

OSHIMA, Nagisa (dir.) (1999). Tabu (Gohatto), Japão.

Risolete Maria Hellmann é Doutoranda da Pós-Graduação em Teoria Literária da Universidade Federal de Santa Catarina, Coordenadora de Pesquisa e Professora do Instituto Federal de Santa Catarina - Campus Florianópolis-Continente em Florianópolis. risolete@gmail.com 